\title{
The Influence of Age and Dietary Conditions on Diabetes in the Db Mouse
}

\author{
B.M. WYSE and W.E. DULIN
}

\author{
Diabetes Research, The Upjohn Company, Kalamazoo, Michigan, USA
}

\begin{abstract}
Summary. The mutant mouse, C57BL/KsJ-db, develops spontaneous diabetes with many symptoms similar to those observed in the diabetic human. Food intake, body weight, and plasma insulin in the $d b$ mouse were increased by 4 weeks of age and blood sugar by 7 weeks. The blood sugar continued to increase with age but by 3 months plasma insulin, pancreatic insulin, and body weight decreased despite continued elevated food intake. Blood sugar and plasma insulin could be stabilized and pancreatic insulin increased of young diabetics were kept on a limited diet. Baseline glucose oxidation by adipose tissue in vitro was elevated in weanling $d b$ mice but depressed in older diabetics. The response to insulin of adipose tissue from older $d b$ mice was markedly reduced and gluconeogenic enzymes were increased. These observations suggested that diabetes in the $d b$ mouse results from the eventual inability of the pancreas to control a continual, abnormally increased supply of glucose. In the very young diabetics, elevated plasma insulio and increased glucose oxidation by the tissues (adipose tissue) maintained the glucose concentration at a normal level. In the older $d b$ 's, elevated food intake, depressed glucose utilization, and continuous output of glucose by the liver produced a constant, severe stress on the beta cells, resulting eventually in beta cell exhaustion and in the development of lethal diabetes.
\end{abstract}

Influence de l'âge et des conditions alimentaires sur le diabète de la souris db

Résumé. La souris du mutant C57BL/KsJ-db développe un diabète spontané dont beaucoup de symptômes ressemblent à ceux du diabète humain. La prise de nourriture, le poids corporel et l'insulinémie de la souris $d b$ sont augmentés dès la 4e semaine, celle du glucose sanguin dès l'âge de 7 semaines. Le sucre sanguin continue à augmenter avec l'âge mais, dès le 3 mois, l'insulinémie, lo contenu du pancréas en insulin et le poids corporel diminuent en dépit d'une prise alimentaire élevée. Le taux de glucose sanguin et l'insulinémie peuvent être stabilisés, le contenu pancréatique en insuline augmente si les jeunes animaux diabótiques sont soumis à une restriction alimentaire. - L'oxidation basale du glucose par le tissue adipeux in vitro est élevée chez la souris $a b$ après le sevrage, mais abaissée chez les animaux dia- bétiques plus âgés. La réponse du tissu adipeux à l'insuline chez les souris $d \vec{b}$ âgées est considérablement diminuée et l'activité des enzymes de la gluconéogénèse est augmentée. Ceci suggère que le diabète de la souris $d b$ serait dù au fait qu'à la longue, le pancréas ne peut contrôler une production de glucose continuellement et anormalement augmentée. Chez les très jeunes animaux diabétiques, l'insulinémie élevée et l'oxidation accrue du glucose par les tissus. (tissu adipeux) contribuent à maintenir le taux de glucose à niveau normal. Chez les souris $d b$ plus âgées, une prise alimentaire augmentée, une utilisation abaissée du glucose et la production continue de glucose par le foie provoquent un stress constant et sévère sur les cellules $\beta$, qui finit quelquefois par épuiser ces dernières et conduit à un diabète léthal.

Einflu $\beta$ von Alter und Nahrungsaufnahme auf das diabetische Syndrom der dbdb-Maus

Zusammenfassung. Die Mäuse des Starnmes C57BL/ $K_{s} J-d b$ entwickeln spontan ein hyperglykämisches Syndrom, das dem Diabotes des Menschen in mancher Hinsicht entspricht. Nahrungsaufnahme, Körpergewicht und Plasmainsulinkonzentrationen der $d b / d b$ Mäuse waren bereits im Alter von 4 Wochen, die Blutzuckerkonzentration im Alter von 7 Wochen erhöht. Während die Blutzuckerkonzentrationen mit steigendem Alter progressiv anstiegen, begannon nach dem 3. Monat Plasmainsulinkonzentration, Insulingehalt des Pankreas und Körpergewicht abzusinken, obwohl die Hyperphagie weiterhin anhielt. Kalorienrestriktion bei jungen Tieren führte zu einer Stabilisierung von Blutzucker- und Plasmainsulinkonzentrationen und zu einer Zunahme des Insulingehalts des Pancreas. In vitro zeigte das Fettgewebe eben abgestillter $d b / d b$ Mäuse erhöhte Glucoseoxidation, während dasjenige älterer diabetischer Tiere sowohl spontan als auch in Gegenwart von Insulin weniger Glucose oxidierte. Die Alktivitäten der Schlüsselenzyme der Gluconeogenese in der Leber waren bei $d b / d b$ Mäusen erhöht. Es wird angenommen, daß der Diabetes der $d b / d b$ Maus auf die Un. fähigkeit des Pankreas zurückzuführen ist, den kontinuierlich erhöhten Anfall von Glucose zu bewältigen.

Key-words: Spontaneous diabetes, heredity, mouse, age, diet, $d b$-mouse, insulin, B-cells.
The diabetic mouse ( $d b$ ) was first described by Hummel et al. [8] and some of the characteristic changes in this diabetic animal were defined in more detail in later publications by Coleman and Hummel $[2,3]$. The studies presented in this paper were done to further characterize the changes which occur with age in the $d b$ mouse, and to determine the influence of restricted diet on these changes.

\section{Materials and Methods}

Animals. All C $57 \mathrm{BL} / \mathrm{K}_{\mathrm{sJ}}-d b$ ( $d b$ or diabetic) and C $57 \mathrm{BL} / \mathrm{KsJ}$ (KsJ or nondiabetic) mice were obtained from the Jackson Laboratories, Bar Harbor, Maine.
All were males except several animals used in the limited diet study as described below. Animals were fed Purina Mouse Breeder Chow and maintained in plastic cages with stainless steel dividers with each cage divided into four equal parts.

Limited diet studies. In one group, ad libitum and limited diet studies were started at 6 weeks of age and in the second group, at 9 weeks of age. Those animals which were started at 6 weeks were continued on the diet for 3 months and those started at 9 weeks for $21 / 2$ months. The animals on limited diet received $2.5 \mathrm{~g} /$ $24 \mathrm{~h}$. Data from these two studies were pooled since identical results were obtained in each study. All except 4 of the KsJ's were males (2 females in the ad libitum 
group and 2 females in the limited diet group). In the $d b$ group, all were males except 1 on the ad libitum diet and 1 on limited diet. Pancreatic insulin and glucose${ }_{11}^{14} \mathrm{C}$ oxidation by adipose tissue were measured at the end of the limited diet study. Body weight, blood sugar and plasma insulin were measured at intervals during the course of the experiment.

Glucose tolerance study. Glucose tolerance studies were done by injection of $2 \mathrm{~g} / \mathrm{kg}$ of glucose I.P. after an overnight fast (approximately $18 \mathrm{~h}$ ). Blood sugars were measured at $1 / 2$ or $2 \mathrm{~h}$ following glucose injection. Fed and fasted blood sugars and plasma insulins were also measured in these mice at least 2 weeks prior to the glucose tolerance test.

Food intake measurements. Food intake was measured by a relatively crude method. which did not control waste and it was assumed that each animal would waste approximately the same percentage of food. Food intake was measured by difference in weight over $5-7$ day periods. In young mice it was measured for one 4-day period from age $27-31$ days of age in the $d b$ mice and 29-33 days of age in the KsJ mice. In the older $d b$ 's and Kst's, food intake was measured in one group from 6-14 weeks and in the second group from $8-20$ weeks of age. Food intake of $d b$ mice was the same in both experiments. This was also true of the KsJ's. Therefore, the data from both studies were pooled.

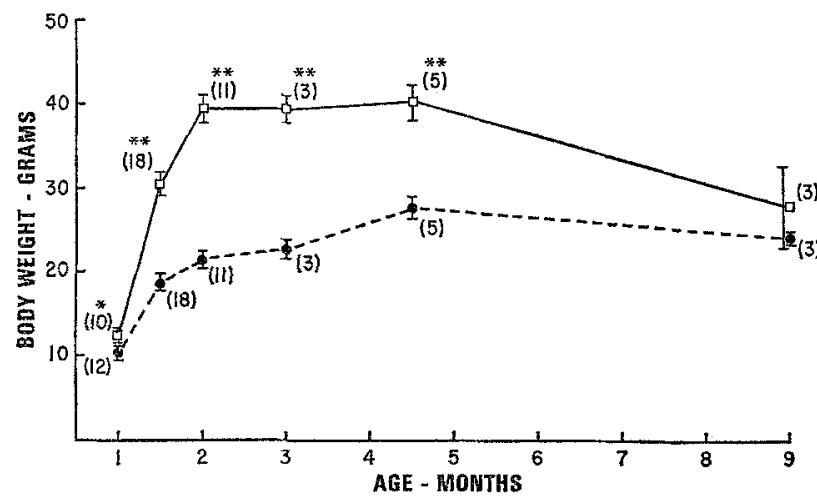

Fig. 1. Woight ehange with age in $d b$ and KsJ mice

$\square=d b$ mice

$0=\mathrm{Ks} \mathrm{J}$ mice

$\mathrm{I}=$ Standard error of the mean

()$=$ Number of animals

$*=P<0.05$

$* *=P<0.001$

Biochemical and tissue analysis. Blood samples used for blood sugar and plasma insulin analysis were obtained from the orbital sinus [11]. Glucose was analyzed in whole blood by the AutoAnalyzer micro procedure which uses a modification [5] of a method described by Hoffman [7]. Plasma insulin was determined by a modification [6] of a double antibody system originally described by Morgan and Lazarow [9]. Glucose oxidation by epididymal adipose tissue was studied in vitro by a procedure described previously [5] and measured ${ }^{14} \mathrm{CO}_{2}$ released by tissues incubated in vitro for $90 \mathrm{~min}$ in a buffer containing ghcose-1-14 $\mathrm{C}$. Pancreatic insulin was determined in extracts of tissue prepared by grinding the individual pancreas in an acid alcohol solution [6] and the assay was carried out on several dilutions of the crude extract by the double antibody technique.

\section{Results}

Diabetic mice were slightly heavier than the nondiabetic animals at 4 weeks of age and gained weight more rapidly until 2 months of age when body weight plateaned at approximately $40 \mathrm{~g}$. The body weights of normal animals reached a plateau of $20-22 \mathrm{~g}$ at approximately 2 months. Between the ages of $4.5-9$ months, diabetic animals lost approximately one-third of their weight while normal animals maintained their body weight (Fig. 1).

Table 1. Studies on young $d b$ and $K s J$ mice

\begin{tabular}{|c|c|c|c|c|c|c|}
\hline No. & Type & $\begin{array}{l}\text { Age } \\
\text { (dayss }\end{array}$ & $\begin{array}{l}\text { Blood } \\
\text { sugar }\end{array}$ & $\begin{array}{l}\text { Plasma } \\
\text { insulin } \\
(\mu \mathrm{U} / \mathrm{mI})\end{array}$ & $\begin{array}{l}\text { Body } \\
\text { weight } \\
\text { (g) }\end{array}$ & $\begin{array}{l}\text { Food } \\
\text { intake }\end{array}$ \\
\hline 0 & $\mathrm{db}$ & $\begin{array}{l}31 \\
29\end{array}$ & & $\begin{array}{r}25 \pm 2 \\
138 \pm 22\end{array}$ & $\begin{array}{l}10.2 \pm 0.3 \\
12.3 \pm 1 \mathrm{~d}\end{array}$ & $\begin{array}{l}2.8^{\mathrm{a}} \pm 0.1 \\
5.2^{\mathrm{b}} \mathrm{c} \pm 0.4\end{array}$ \\
\hline
\end{tabular}

a Mea sured 29-33 days of age.

b Measured 27-31 days of age.

e $P=<0.01$

d $P=<0.05$

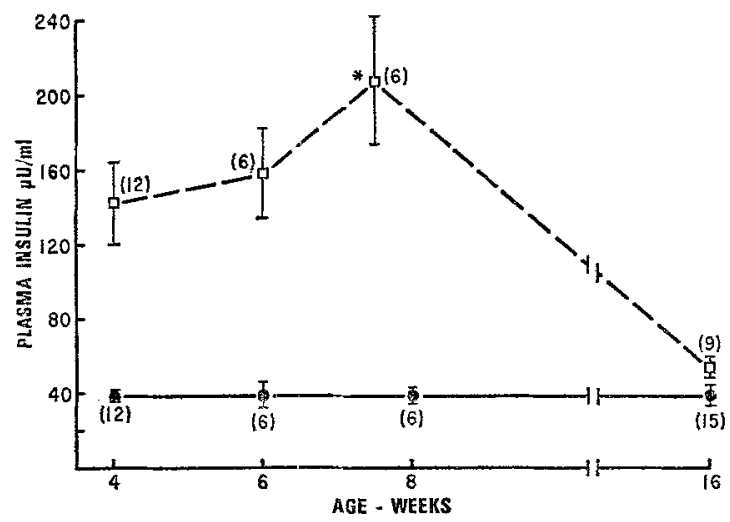

Fig. 2. Effect of age on plasma insulin of $d b$ and KsJ mice $\square=d b$ mice

= KsJ mice

$\mathbf{I}=$ Standard error of the mean

()$=$ Number of animals

${ }^{*}=P<0.001$

As early as 1 month of age and throughout the observation period, the diabetic mice consumed 5-6 g of food/day/animal while the controls consumed 2.5$3 \mathrm{~g}$ of food/day/animal (Table 2).

The plasma insulins of $d b$ mice were elevated by 4 weeks of age and increased until the animals were 2.5 months of age, after which they began to decrease 
toward control levels by 3-4 months of age (Fig. 2). The plasma insulins of the $\mathrm{K}_{\mathrm{sJ}} \mathrm{m}$ mice remained relatively constant throughout this time period (Fig. 2). Fasting plasma insulins were lower than fed plasma insulins in both the $d b$ and KsJ mice. However, the fasting insulins in the $d b$ mice were higher than the fed insulins of the $\mathrm{KsJ}$ mice.

Table 2. Food intake of $d b$ and $K s J$ mice

\begin{tabular}{rlcl}
\hline No. & Type & $\begin{array}{l}\text { Age during food } \\
\text { measurements }\end{array}$ & $\begin{array}{l}\text { Average intake } \\
(\mathrm{g} / 24 \mathrm{~h})\end{array}$ \\
\hline 8 & $\mathrm{KsJ}$ & $7-17$ weeks & $2.9 \pm 0.2$ \\
5 & $\mathrm{db}$ & $7-17$ weeks & $5.8 \pm 0.4^{\mathrm{a}}$ \\
12 & $\mathrm{KsJ}$ & $29-33$ days & $2.8 \pm 0.1$ \\
10 & $\mathrm{db}$ & $27-31$ days & $5.2 \pm 0.2^{\mathrm{a}}$ \\
\hline
\end{tabular}

$\mathrm{a}=P<0.01$ between $\mathrm{KsJ}$ and $d b$ mice.

Pancreatic insulin of $d b$ mice was slightly decreased by 4 weeks of age and continued to decrease for about 2-3 months to a value less than $1 / 2$ of normal. Pancreatic insulin of the control mice remained fairly constant with age (Fig. 4).

Baseline oxidation of glucose-1. ${ }^{14} \mathrm{C}$ by adipose tissue in vitro was elevated in tissues from 4-week old $d b$ mice and the response of these tissues to insulin was normal or slightly elevated. Tissues from 2.5 month or older diabetics showed a reduced baseline glucose oxidation and reduced response to insulin (Fig. 5).

Gluconeogenic enzymes and glycolytic enzymes of the liver were elevated in 2-month old $d b$ mice. By 4.5 months, the gluconeogenic enzymes had increased further but the glycolytic enzymes had decreased [1].

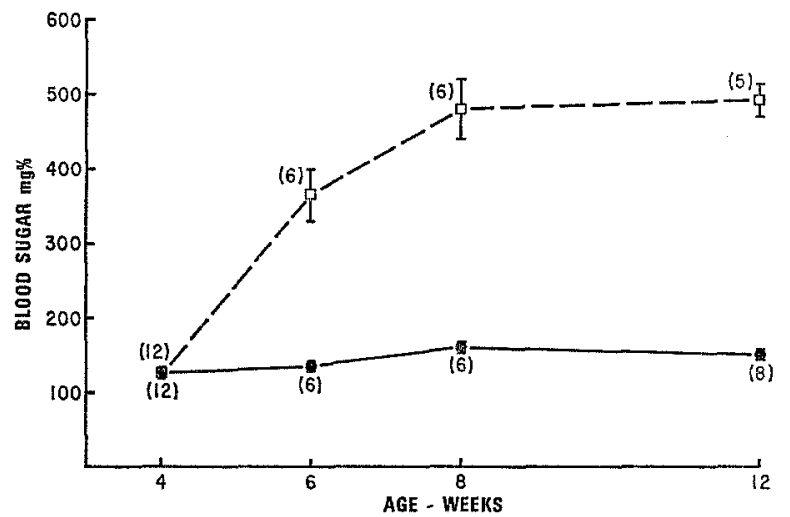

Fig. 3. Effect of age on blood sugar of $d b$ and KsJ mice $\square=d b$ mice $\quad I=$ Standard error of the mean

$=\mathrm{KsJ}$ mice $\quad()=$ Number of animals

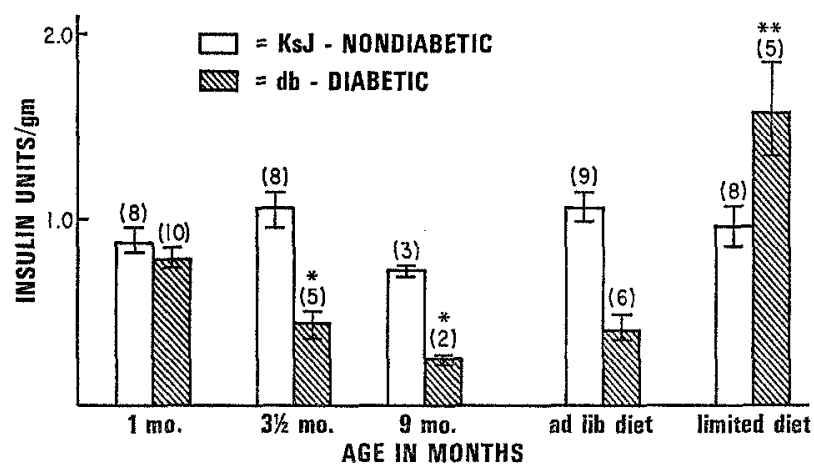

Fig. 4. Pancreatic insulin of $d b$ and $\mathrm{KsJ}$ mice

$I=$ Standard errox of the mean $\quad *=P<0.05$

$(\mathrm{I})=$ Number of animals $\quad * *=P<0.001$
Fig. 5. Effect of age on glucose $1-{ }^{14} \mathrm{C}$ oxidation by epididymal fat pads of $\mathrm{K}_{\mathrm{S}} J$ and $d b$ mice

$\mathrm{I}=$ Standard error of the mean

()$=$ Number of fat pads

* $=P<0.05$

$* *=P<0.001$

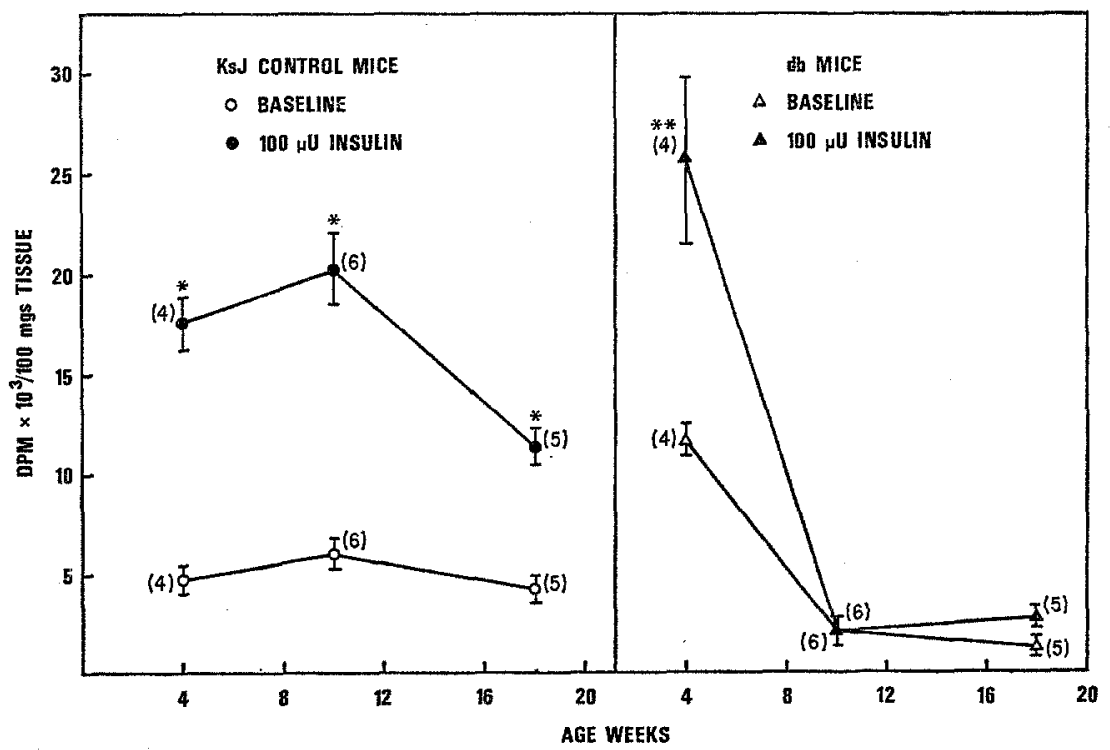

Blood sugars of the diabetic mice were normal at 4 weeks, but increased throughout the $3-4$ months of observation to a maximum of over $500 \mathrm{mg} \%$. The greatest rate of increase occurred when the plasma in- sulin and body weight began to fall. Blood sugars of the nondiabetics remained stable during the period of observation (Fig. 3). Fasting blood sugars were lower than the fed sugars in both groups of mice, but the fasted 
sugars of $d b$ mice were higher than the fed sugars of normal mice.

Glucose tolerance values in the $d b$ mice were abnormal. Blood sugars were elevated $1 / 2$ and $2 \mathrm{~h}$ after the glucose load. Despite elevated blood sugars, plasma insulins were not as high as those observed in the fasted state $14-22$ days earlier, but they were still higher than insulins from control animals (Table 3).

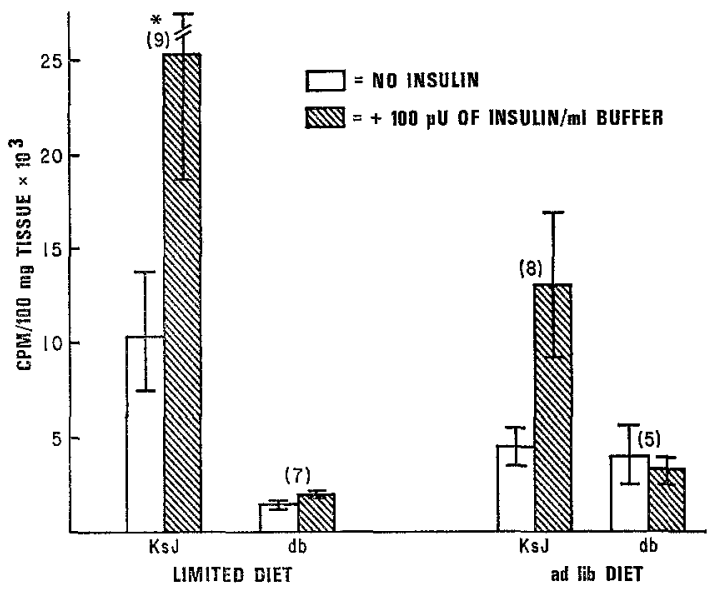

Fig. 6. Glucose $1{ }^{14} \mathrm{C}$ oxidation by epididymal fat pads of KsJ and $d b$ mice on ad libitum or limited diet

$I=$ Standard error of the mean

( ) = Number of fat pads

* $=P<0.05$

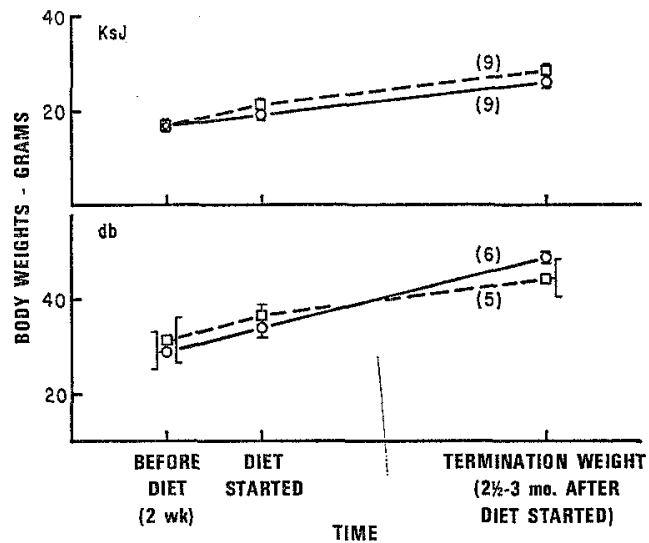

Fig. 7. Effect of limited diet on body weights of $d b$ and KsJ mice

$\square=$ Ad libitum
$0=$ Limited diet $\quad()=$ Number of animals
$\mathbf{I}=$ Standard error of the mean

Effect of limiting diet: When $d b$ mice were placed on a limited diet of $2.5 \mathrm{~g}$ of food/day/animal, some of the diabetic symptoms were minimized. Blood sugars of the $d b$ mice on the limited diet stabilized at pre-diet levels while blood sugars of $d b$ animals on an $a d l i b$ diet continued to increase. Blood sugars of control mice on both $a d l i b$ and limited diet remained constant throughout the experiments (Fig. 8).

Plasma insulins of $d b$ mice on limited diet stabilized and remained at relatively high levels while plasma insulins of the $d b$ animals fed $a d l i b$ decreased to near control values (Fig. 9). Pancreatic insulins of $d b$ mice maintained on limited diet increased to levels greater than those of control mice. Pancreatic insulins of $d b$ mice on an ad libitum diet decreased to below control values (Fig. 4).

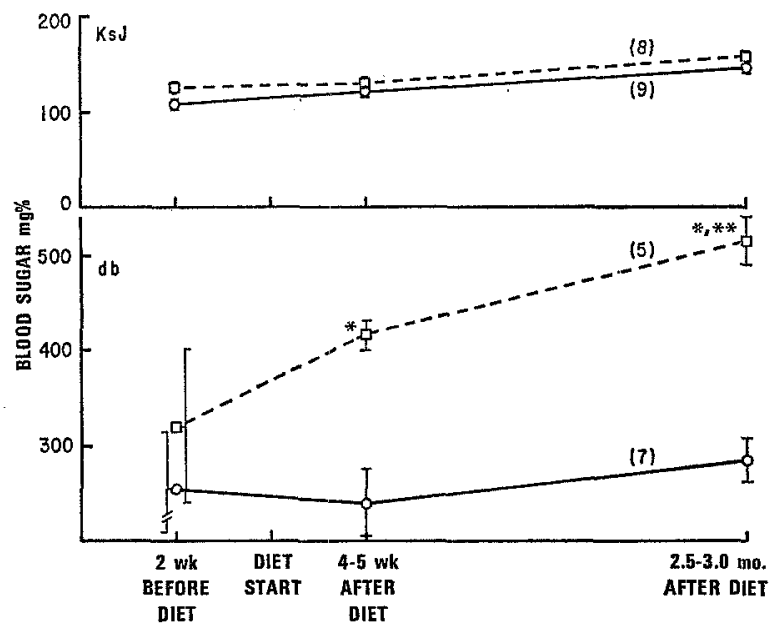

Fig. 8. Effect of limited diet on blood sugar of $K_{s J}$ and $d b$

$\square=$ Ad libitum

$0=$ Limited diet

()$=$ Number of animals

$I=$ Standard error of the mean

$*=P<0.01$ between ad libitum and limited diet

$* *=P<0.01$ between 2 weeks before diet and $2.5-3.0$ months after diet

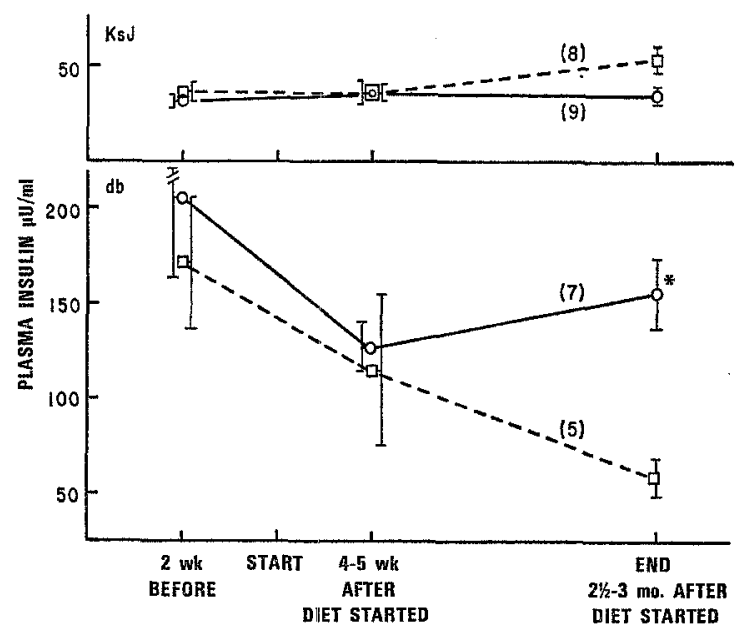

Fig. 9. Effect of limited diet on plasma insulin of $d b$ and $\mathrm{KsJ}$ mice

$\square=$ Ad libitum

$0=$ Limited diet

$($ ) $=$ Number of animals

$I=$ Standard error of the mean

$*=P<0.01$

Body weights of $d b$ mice on a limited diet increased at a steady rate during the experiment (Fig. 7). Body weights of diabetics on ad libitum diet began to in- 
crease at a slower rate after about 3 months of age so that eventually their body weights were somewhat lower than those of the mice on limited diet. The weights of the controls maintained on an $a d$ lib diet and on limited diet increased slowly, with weights of those on $a d$ lib diet being slightly higher than those on limited diet. It should be noted that both $a d l i b$ and limited diet control groups ate approximately $2.5 \mathrm{~g}$ of food per day.

The ability of the adipose tissue in diabetic animals to oxidize glucose and respond to insulin was not increased by maintaining the animals on a limited diet which was equivalent to what the control animals ate. Glucose oxidation and insulin response remained depressed in adipose tissue from animals on both limited and $a d$ lib diets (Fig. 6). by increased gluconeogenic enzymes and increased conversion of pyruvate to glucose [1], and 2. glucose utilization was decreased as shown by decreased glycolytic enzyme levels in the liver and decreased glucose oxidation by adipose tissue. As these conditions continued, the beta cells were apparently unable to keep up with the continuous and severe demands placed upon them. Supporting this were the observations of decreased pancreatic and plasma insulins. A continuation of this state resulted in final exhaustion of the beta cells and a severe and lethal diabetes. Apparently the beta cells of the $d b$ mouse were not able to meet the excessive demands for insulin as is the case of some of the other abnormal mice, such as the KK $[10,4]$. In the KK mouse in contrast to the $d b$ mouse, the beta cells and pancreatic islets increase in number and size resulting

Table 3. Blood sugar and plasma insulin from fed, fasted and during $1 / 4$-of 2-h I.P. glucose (2 g/kg) tolerance test $(G T T)$ in Bar Harbor $(d b)$ diabetic mice

\begin{tabular}{|c|c|c|c|c|c|c|c|c|}
\hline \multirow[b]{2}{*}{ No. } & \multirow{2}{*}{\multicolumn{2}{|c|}{$\begin{array}{c}\text { Body } \\
\text { Type mouse weighta }\end{array}$}} & \multicolumn{2}{|l|}{ Fed } & \multicolumn{2}{|l|}{ Fasted } & \multicolumn{2}{|l|}{ GTT } \\
\hline & & & $\begin{array}{l}\text { Blood } \\
\text { sugar }\end{array}$ & Insulin & $\begin{array}{l}\text { Blood } \\
\text { sugar }\end{array}$ & Insulin & $\begin{array}{l}\text { Blood } \\
\text { sugar }\end{array}$ & Insulin. \\
\hline & & & $(42)^{d}$ & & (51) & & $\begin{array}{l}(73) \\
1 / 2-h\end{array}$ & GTT \\
\hline 6 & C57BL/KsJ & $19.8 \pm 0.3$ & $167 \pm 8$ & $32 \pm 5$ & $76 \pm 4^{e}$ & $8 \pm 6$ & $192 \pm 8$ & $23 \pm 3$ \\
\hline 6 & & $31.6 \pm 0.2^{\mathrm{b}}$ & $\begin{array}{l}419 \pm 22^{b} \\
(60)\end{array}$ & $217 \pm 27 b$ & $\begin{array}{l}240 \pm 43^{\mathrm{b}, \mathrm{c}} \\
(74)\end{array}$ & $112 \pm 14^{b, c}$ & $\begin{array}{l}703 \pm 26^{\mathrm{b}} \\
(88) \\
2 \mathrm{~h} \text { GTT }\end{array}$ & $67 \pm 9^{b}$ \\
\hline 5 & $\mathrm{C} 57 \mathrm{BL} / \mathrm{K}$ sЈ & $20.8 \pm 0.8$ & $143 \div 8$ & $43 \pm 7$ & $85 \pm 6^{\mathrm{c}}$ & $20 \pm 4^{\mathrm{e}}$ & $125 \pm 5$ & $11 \pm 2$ \\
\hline 5 & $\mathrm{db}$ & $40.7 \pm 0.5^{b}$ & $421 \pm 12^{b}$ & $213 \pm 24^{b}$ & $172 \pm 13^{\mathrm{b}, \mathrm{c}}$ & $153 \pm 28^{b, c}$ & $662 \pm 39 b$ & $73 \pm 10^{\mathrm{b}}$ \\
\hline
\end{tabular}
a At time of fed measurements.
b $P<0.01$ compared to C57BL/KsJ.
c $P<0.01$ compared to fed.
d ()$=$ age in days.

The elevated level of gluconeogenic enzymes was partially reduced and glycolytic enzymes increased when $d b$ mice were maintained on limited diet [1].

\section{Discussion}

Data presented in this paper confirmed the results of Coleman and Hummel [2] and showed plasma insulin of $d b$ mice was increased at an early age but fell toward control levels by $12-16$ weeks. Pancreatic insulin was generally decreased at all ages. Blood sugar was normal in young $d b$ mice but increased rapidly between $4-8$ weeks of age.

Increased glucose utilization may explain why the 4-week old hyperphagic $d b$ mouse has normal blood sugar levels. The evidence for this is: inereased conversion of glucose to $\mathrm{CO}_{2}$ in vivo [2], increased glucose utilization by adipose tissue, and increased glucose utilization by liver as indicated by increased glycolytic enzymes [1]. With increased age, a number of changes occur in the $d b$ mice which result in the deterioration of their condition. The most striking changes observed were: 1. hepatic glucose output was increased as shown in a continuous increased supply of insulin which is sufficient to satisfy the need.

The available data do not allow definition of the earliest change in the $d b$ mouse. It is not clear if the first change is increased food intake or increased insulin secretion which would be expected to result in increased food intake [3]. There was little doubt that the increased food intake was an important factor in the development of the diabetic syndrome in the $d b$ mouse since limiting the diet stabilized plasma insulin, reduced the gluconeogenic enzymes, increased hepatic glycolytic enzymes and elevated pancreatic insulin. Further, the data suggest that diet limitations prior to pancreatic exhaustion may allow the animal to cope with a slightly excessive supply of glucose. However, limiting the food intake did not normalize plasma insulin, body weight or response of adipose tissue to insulin. The fact that limiting the diet to normal intake still allowed an excessive weight gain suggested that the elevated insulin levels play an important role in the development of obesity in the $d b$ mice.

If the earliest change in the $d b$ mouse is to be defined, it seems clear that food intake and plasma in- 
sulins must be measured from the time of birth. It is possible that experimental procedures can be designed to control food consumption during the pre-weaning stage. If food restriction normalized insulin secretion, it would support the hypothesis that the primary change was increased food consumption.

\section{References}

1. Chang, A.Y., Schneider, D.I.: Abnormalities in hepatic enzyme activities during development of diabetes in $d b$ mouse. Diabetologia, this issue.

2. Coleman, D.L., Hummel, K.P.: Studies with the mutation, diabetes, in the mouse. Diabetologia 3, $238-248,1967$.

3. - - The mutation, diabetes, in the mouse. Proceedings of the 6th Congress of the International Diabetes Federation, Stockholm, Sweden, July 30August 4, 1967. Ed. by Ostman, J. pp. $813-820$. Amsterdam: Excerpta Med. Foundation 1969.

4. Dulin, W.E., Wyse, B.M.: Diabetes in the KK mouse. Diabetologia, this issue.
5. Gerritsen, G.C., Dulin, W.E.: Effect of a new hypoglycemic agent, 3,5 dimethylpyrazole on carbohy. drate and free fatty acid metabolism. Diabetes 14, $507-515$ (1966).

6. - - Characterization of diabetes in the Chinese hamster. Diabetologia 3, 74-84 (1967).

7. Hoffman, W.S.: A rapid photoelectric method for the determination of glucose in blood and urine. J.B.C. 120, $51-55(1937)$.

8. Hummel, K.P., Coleman, D.L.: Diabetes, a new mutation in the mouse. Science 153, 1127-2228 (1966).

9. Morgan, C.R., Lazarow, A.A.: Immunoassay of insulin; two antibody system. Diabetes 12, 115-126 (1963).

10. Nakamura, M., Yamada, K.: Studies on a diabetic (KK) strain of the mouse. Diabetologia 3, 212-221 (1967).

11. Riley, V.: Adaptation of orbital bleeding technique to rapid serial blood stadies. Proc. Soc. exp. Biol. Med. 104, $751-754$ (1960).

B.M. Wyse, M.S.

Diabetes Research

The Upjohn Company

Kalamazoo, Michigan, USA 